ГЕОЭКОЛОГИЯ

УДК 550.9.1

ISSN 1609-0683

DOI: https://doi.org/10.17308/geo.2020.2/2886

\title{
Об особо охраняемых природных территориях Западного Казахстана
}

\author{
А. А. Тургумбаев \\ Западно-Казахстанский государственный университет им. М. Утемисова, Республика Казахстан \\ (090000, г. Уральск, пр. Нурсултан Назарбаев, 162)
}

\begin{abstract}
Аннотация: Цель: концентрировать внимание научной общественности и административных органов Западно-Казахстанской области на необходимость организации ООПТ на месте распространения степных ландшафтов «Рын песков». Методы и материалы. На территории области находятся 10 объектов природно-заповедного фонда. Из них три имеют статус государственных заказников, а семь объектов отнесены к охраняемым территориям с разными природными функциями: гидробиологическими, ботаническими, ландшафтными, ландшафтно-биосферными, зоологическими и комплексными. В Западно-Казахстанской области земли особо охраняемых природных территорий составляют 12,4 тыс. га. При исследовании территории «Рын песков» на площади около 300-350 тыс. га были использованы космические материалы, полевые экспедиционные исследования и литературные данные. Результаты. Степной ландшафт «Рын песков» значительно изменил свой облик за последние 6070 лет под влиянием пастьбы скота.
\end{abstract}

Ключевые слова: охраняемые земли, заказники, гряды, ландшафт, пески, бугры.

Для цитирования: Тургумбаев А.А. Об особо охраняемых природных территориях Западного Казахстана // Вестник Воронежского государственного университета. Серия: География. Геоэкология, 2020, № 2, c. 55-58. DOI: https://doi.org/10.17308/geo.2020.2/2886

\section{ВВЕДЕНИЕ}

Вопрос об особо охраняемых землях в пределах Западного Казахстана остается открытым. Часто среди чиновников, да и среди отдельных ученых можно услышать: «Что в степи охранять? Степь однообразна!». Вот почему в нашем регионе степных ландшафтов охраняется не более 1-2\%, а именно: отдельные участки долины реки Жайык (Урал), лес посаженный ханом Букеем, отдельные озера и некоторые другие территории такие, как гора Малое Богдо, гора Ичка и горы Миргородка. Следует не согласится с выводами о степи, что степь однообразна. Степь очень разнообразна. На одном километре можно встретить очень пеструю растительность, различные почвы и микрорельеф. К изучению и использованию ландшафтов степи следует подходить очень осторожно и разнообразно, что в настоящий момент к сожалению многое упущено, а многие вопросы по развитию степи

(C) Тургумбаев А.А., 2020

凶 E-mail: akan.86@mail.ru даже не рассматриваются. А казахские степи имеют очень плодородные почвы. На их площади можно выращивать пшеницу, овощи и фрукты. Это знали наши предки. Около поселка Урда были фруктовые сад, а в Джанибекском районе Западно-Казахстанской области сотрудники академии наук СССР получали небывалые урожай зерновых, овощных и плодовых культур.

Но кроме эксплуатации степных просторов необходимо сохранить отдельные участки степи в ее первозданном виде. Таких участков еще осталось много, но необходимо сделать правильный выбор и знать, что мы хотим сохранить растительный покров, почвы ил ландшафт в целом.

\section{МЕТОДЫ ИССЛЕДОВАНИЯ}

Предметом нашего исследования стала территория расположенная в 4 км к западу от пос. Урда по проселочной дороге Урда-Шалак-Талей, по северо-восточному побережью оз. Хаки, включая

cc) (i) Контент доступен под лицензией Creative Commons Attribution 4.0 License.

Вестник ВГУ, Серия: География. Геоэкология, 2020, № 2, 55-58 
пески Мешеткум, Кызылкум, Карагали, Карабудыр к зимовьям Магаз и Закеш. Далее по проселочной дороге на северо-запад через зимовья Туксунали и Коккамыс, южнее пос. Бисен. Общая площадь составляет 300-350 тыс. га. Климатические особенности территории расположены в умеренном климатическом поясе [1].

При исследовании территории «Рын песков» на площади около 300-350 тыс. га были использованы космические материалы, полевые экспедиционные исследования и литературные данные.

Хочу предложить, чтобы сохранить Урдинские (Нарынские) пески идущие вдоль оз. Хаки для потомков создать здесь ООПТ. Это небольшая по площади территория протянулась с запада на восток, около 40 км и около 25-30 км с севера на юг. Урдинские пески представляют собой систему гряд шириной до 5-8 км, раздельные межгрядовыми понижениями. Ширина межгрядовых понижений до 5 км. Гряды ориентированы с северо-запада на юго-восток. Относительная высота гряд над межгрядовыми понижениями превышает 30 м. Название Урдинских песков «Рын пески» - это искаженное слово «Рын» от слова «Нарын», что означает в переводе с казахского «лента». Рын пески иначе «ленточные пески». Это название определяет их строение, которое детально описал в 50-х годах Т. Ф. Якубов.

Следует обратить внимание, что склоны гряд в середине XX века были обрывистыми, а к настоящему времени они выполаживаются. Растительность уничтожается в результате выпаса скота, песок без скрепления растениями осыпается и склоны разрушаются. Если рассматривать топографические карты съемки 1930-1940 годов то видим, что в межгрядовых понижениях были солончаки и небольшие соленые озера. В настоящее время все это засыпано песком. Межгрядовые понижения засыпаются песком и днища их медленно повышаются. Урдинские пески - это древняя дельта. Урдинские грядовые пески - уникальное природное сооружение на месте морского залива, существовавшего 30 тыс. лет назад. В него впадали реки Ащеузек, Большой и Малой Узень, Чижа, Балыкта и многие другие. Реки были полноводными. Они несли огромное количество песчаного материала и он аккумулировался. При акчагыльской регрессии море отступало на некоторое время, но позднехвалынская трансгрессия поднимала его до абсолютной отметки 0 метров и вода поднималась. Увеличивался объем приносимого реками песчано-глинистого материала. Непродол- жительная трансгрессия вновь сменялась регрессией. Водные потоки северных рек вслед за отступающим морем врезаются в отложенный песчаноглинистый материал, образуя аккумулятивную дельту. Почему дельту называет аккумулятивной? Ответ прост. Здесь с размывом песчанно-глинистых масс происходит и их накопление. В первую очередь идет накопление песков. Это более тяжелое фракция и она выпадает из постепенно слабеющих водных потоков. Так формируются гряды. Текущие воды формируют межгрядовые понижения, где идет накопление более мелких фракций. К концу позднехвалынского времени море спустилось на абсолютную отметку - 10 метров. Большая часть Северного Прикаспия освободилась от морских вод. Хакский залив принимает вытянутую форму и сокращает свои размеры. Дельта завершает свое развитие. Там, где водный поток между грядами прекратил свое существование возникли озера с пресными или слабо засоленными водами [2]. Со временем озера по межгрядовым понижениям высыхают, превращаясь в солончаки, а со временем засыпаются песком, гряды разрушаются. Кучевые пески, заросшие первоначально засухоустойчивыми растениями разрушается и переходят в барханные. Гряды теряют свою высоту и выположываются.

Песчаные котловины заняты в основном сосновыми лесами. Диаметр песчаных котловин в среднем составляет 20-30 м, глубина около 3-4 метров. Дно почти ровное, а вокруг котловин сохраняются песчаные бугры с высотой около 7-8 метров. Дно котловин занято кустарниково-сосновыми растительными ассоциациями. Проективное покрытие составляет 10-15\%. В видовом составе доминируют сосна (Pinus), ива (Salix), джунгун (Calligonum). Бугры заняты в основном полынью песчаной (Artemisia), молочаем (Euphorbia), мятликом (Poa), осокой (халхитской) (Carex), хондриллой щитковидной (Chondrilla juncea L.), васильком (Centau$r e a)$, а также встречаются иные степные псамофитные растения. Высота сосны доходят до 20-30 м, а тополь нарынский поднимается до 10 метров.

\section{ЗАКЛЮЧЕНИЕ}

В настоящее время это сухая дельта «Рын песков» - уникальное природное сооружение. Подобных дельт нет на всей территории Средней Азии. Актуально детальное ее изучение. Тем более, что опыт изучения степных ландшафтов России известен [1]. Территория сухой дельты у поселка Урда заслуживает того, чтобы стать заповедной особо охраняемой территорией. 


\section{СПИСОК ЛИТЕРАТУРЫ}

1. Соколов А.А. Опыт территориальной оценки эффективности использования биопотенциального плодородия степной зоны России // Вестник Воронежского государственного университета. Серия География. Геоэкология, 2018, № 1, с. 73-77.

2. Тургумбаев А.А., Турикешев Г. Т.-Г. Структурные особенности современного рельефа и вопросы па- леогеоморфологии хвальнского времени Прикаспийской впадины. Уральск, РИЦ ЗКГУ им. М. Утемисова, 2016. 186 c.

Конфликт интересов: Автор декларирует отсутствие явных и потенциальных конфликтов интересов, связанных с публикацией настоящей статьи.

Поступила в редакциию 22.10.2019 Принята к публикаичи 02.06.2020

\title{
GEOECOLOGY
}

\section{On Specially Protected Natural Areas of Western Kazakhstan}

\author{
A. A. Turgumbaev ${ }^{\varpi}$ \\ West Kazakhstan state University. M. Utemisov, Kazakhstan \\ (162, Ave. Nursultan Nazarbayev, Uralsk, 090000)
}

\begin{abstract}
The purpose is to concentrate the attention of the scientific community and administrative bodies of the West-Kazakhstan region on the need to organize protected areas at the place of distribution of the Steppe landscapes "Sand Market". Methods and materials. There are 10 objects of the nature reserve fund in the region. Of these, three have the status of state reserves, and seven objects are assigned to protected areas with different natural functions: hydrobiological, botanical, landscape, landscape-biosphere, zoological and complex. In the West-Kazakhstan region, the lands of specially protected natural areas amount to 12.4 thousand hectares. When exploring the "Sand Market" area on an area of about 300-350 thousand hectares, space materials, field expeditionary research, and literature data have been used. Results. The steppe landscape "Sand Market" has significantly been changed over the past 60-70 years under the influence of cattle grazing.

Key words: protected areas, sanctuaries, ridges, landscape, sands, mounds.

For citation: Turgumbaev A. A. On Specially Protected Natural Areas of Western Kazakhstan. Vestnik Voronezskogo gosudarstvennogo universiteta. Seria Geografia. Geoekologia, 2020, No. 2, pp. 55-58. (In Russ.) DOI: https://doi.org/10.17308/geo.2020.2/2886
\end{abstract}

\section{REFERENCES}

1. Sokolov A. A. Opyt territorial'noy otsenki effektivnosti ispol'zovaniya biopotentsial'nogo plodorodiya stepnoy zony Rossii [The experience of territorial assessment of the effectiveness of using biopotential fertility of the steppe zone of Russia]. Vestnik Voronezskogo gosudarstvennogo universiteta. Seria Geografia. Geoekologia, 2018, no. 1, pp. 73-77. (In Russ.)
2. Turgumbaev A. A., Turikeshev G. T.-G. Strukturnye osobennosti sovremennogo rel'efa i voprosy paleogeomorfologii khvalynskogo vremeni Prikaspiyskoy vpadiny [Structural features of the modern relief and questions of paleogeomorphology of the Khvalyn time of the Caspian depression]. Ural'sk, Publ. STSU M. Utemisova, 2016. 186 p.

Conflict of interests: The author declares no information of obvious and potential conflicts of interest related to the publication of this article.

Received: 22.10.2019

Accepted: 02.06.2020

(C) Turgumbaev A. A., 2020

$\triangle$ E-mail: akan.86@mail.ru

(i) The content is available under Creative Commons Attribution 4.0 License. 


\section{A. A. Turgumbaev}

Тургумбаев Ахан Аскарович

старший преподаватель кафедры географии, Западно-Казахстанский государственный университет им. М. Утемисова, г. Уральск, Казахстан, ORCID: https:/ /orcid.org/0000-0003-2685-5085, e-mail: akan.86@mail.ru
Akhan A. Turgumbaev

Senior Lecturer of the Department of Geography, West Kazakhstan State University named after M. Utemisov, Uralsk, Kazakhstan, ORCID: https://orcid.org/0000-0003-2685-5085, e-mail: akan.86@mail.ru 